\title{
ANALISIS SISTEM AKUNTANSI PELAKSANAAN APBDES PADA PEMERINTAH DESA KOPANDAKAN I KECAMATAN KOTAMOBAGU SELATAN KOTA KOTAMOBAGU
}

\author{
Hadi Prabowo Gimon ${ }^{1}$, Jantje J. Tinangon ${ }^{2}$, Dhullo Affandi ${ }^{3}$ \\ 1,2,3 Jurusan Akuntansi, Fakultas Ekonomi dan Bisnis, Universitas Sam Ratulangi, Jl. Kampus Bahu, Manado, \\ 95115, Indonesia \\ E-mail : hadigimon37@gmail.com
}

\begin{abstract}
Village income and expenditure budget is one of the things that must be considered to realize good governance in the village. The purpose of this study is to analyze the adequacy of the accounting system implementation of APBDes organized by the Kopandakan I village government and whether it is in accordance with the Minister of Home Affairs No. 113 of 2014 on the management of village finances. The method used in this research is qualitative descriptive that is analyze the adequacy of accounting system implementation of APBDes. The results of the research show that 1) Internal control in terms of producing transaction evidence executed by Kopandakan I village government has been running quite well, 2) Recording of APBDes implementation in Kopandakan I village has been done well 3) Reallocation Report of Implementation of APBDes in Kopandakan Village I has been in accordance with Permendagri Number 113 Year 2014; but village officials have problems in the process of implementing APBDes in this case tax cutting activities but directly in consultation with the tax office.
\end{abstract}

Keywords : Accounting system, implementation, APBDes

\section{PENDAHULUAN}

Peran besar yang diterima oleh desa, tentunya disertai dengan tanggung jawab yang besar pula. Oleh karena itu pemerintah desa harus bisa menerapkan prinsip akuntabilitas dalam tata pemerintahannya, dimana semua akhir kegiatan penyelenggaraan pemerintahan desa harus dapat dipertanggungjawabkan kepada masyarakat desa sesuai dengan ketentuan. Dalam hal pengelolaan keuangan desa, pemerintah desa harus menyusun Laporan Realisasi Pelaksanaan APBDes dan Laporan Pertanggungjawaban Realisasi Pelaksanaan APBDes. Laporan ini dihasilkan dari suatu siklus pengelolaan keuangan desa, yang dimulai dari tahapan perencanaan dan penganggaran; pelaksanaan dan penatausahaan; hingga pelaporan dan pertanggungjawaban pengelolaan keuangan desa.

Pengelolaan keuangan desa yang baik adalah pengelolaan yang sesuai dengan pedoman yang telah di atur oleh pemerintah yaitu tertuang pada Permendagri Nomor 113 Tahun 2014 tentang Pengelolaan Keuangan Desa.

Dalam pengelolaan keuangan desa, dalam hal ini pelaksanaan APBDes harus memiliki internal control serta sistem akuntansi yang baik dan memadai agar supaya kualitas laporan keuangan yang dihasilkan bisa di pertanggungjawabkan dengan jelas.

Pengelolaan keuangan desa, dalam hal ini pelaksanaan APBDes harus memiliki internal kontrol serta sistem akuntansi yang baik dan memadai agar supaya kualitas laporan keuangan yang dihasilkan bisa di pertanggungjawabkan dengan jelas.

Berdasarkan latar belakang penelitian yang di angkat di atas maka rumusan masalah pada penelitian ini yaitu Apakah sistem akuntansi yang diselenggarakan oleh pemerintah desa Kopandakan I dalam pelaksanaan APBDes telah memadai ? 
Tujuan dari penelitian ini adalah untuk menganalisis memadai tidaknya sistem akuntansi pelaksanaan APBDes yang diselenggarakan oleh pemerintah desa Kopandakan I.

\section{TINJAUAN PUSTAKA}

\subsection{Standar Operasional Prosedur}

Pengertian SOP Setiap organisasi perusahaan memiliki pola dan mekanisme tersendiri dalam menjalankan kegiatannya, pola dan mekanisme itu melalui prosedur dan pedoman secara manual, oleh karena itu melalui bagian ini akan dijelaskan beberapa pengertian yang berkaitan dengan pola dan mekanisme dalam perusahaan, seperti pengertian SOP dan standar kerja. Prosedur adalah suatu rangkaian metode yang telah menjadi pola tetap dalam melakukan suatu pekerjaan yang merupakan suatu kebulatan (Sayuti, 2012: 2).

1. Analisis Tugas

Analisis tugas merupakan proses manajemen yang merupakan penelaahan yang mendalam dan teratur terhadap suatu pekerjaan, karena itu analisis tugas diperlukan dalam setiap perencanaan dan perbaikan organisasi. Analisis tugas diharapkan dapat memberikan keterangan mengenai pekerjaan, sifat pekerjaan, syarat pejabat, dan tanggung jawab pejabatnya. Berikut lima aspek yang berkaitan dengan analisis tugas: 1)Analisis tugas. 2)Deskripsi tugas. 3) Spesikasi tugas. 4)Penilaian tugas. 5) Pengukuran kerja dan penentuan standar tugas merupakan prosedur penetapan.

2. Analisis Prosedur Kerja

Analisis prosedur kerja adalah kegiatan untuk mengidentifikasi urutan langkahlangkah pekerjaan yang berhubungan dengan apa yang dilakukan, bagaimana hal tersebut dilakukan, dimana hal tersebut dilakukan, bilamana hal tersebut dilakukan, dan siapa saja yang melakukannya. Prosedur diperoleh dengan merencanakan terlebih dahulu bermacammacam langkah yang dianggap perlu untuk melaksanaan pekerjaan.

\subsection{Sistem Pengendalian Internal}

Menurut COSO framework, Internal control terdiri dari 5 komponen yang saling terkait, yaitu:

1. Lingkungan Pengendalian

2. Penaksiran Risiko

3. Aktivitas Pengendalian

Aktivitas pengendalian dapat dikategorikan sebagai berikut.

1) Pengendalian Pemrosesan Informasi

a) pengendalian umum

b) pengendalian aplikasi

c) otorisasi yang tepat

d) pencatatan dan dokumentasi

e) pemeriksaan independen

2) Pemisahan tugas

3) Pengendalian fisik

4) Telaah kinerja

4. Informasi Dan Komunikasi

5. Pemantauan / Monitoring

\subsection{Teori Akuntansi}

Menurut Warren, Reeve, dan Duchac (2011:3), Akuntansi adalah sebuah system informasi yang memberikan laporan kepada pengguna mengenai kegiatan ekonomi dan kondisi dari sebuah bisnis. Sedangkan menurut Sadeli (2015:2) menyatakan bahwa akuntansi digunakan untuk mencatat, meringkas, melaporkan, menginterpretasikan data dasar ekonomi untuk kepentingan perorangan, pengusaha, pemerintah, dan anggota masyarakat lainnya. Akuntansi adalah seni pencatatan, pengklarifikasian dan peringkasan mengenai data 
keuangan, transaksi dan kejadian yang menjadi bagian dari karakteristik keuangan serta menginterpretasikannya (Francis, 2013) sedangkan tujuan utama akuntansi adalah menyajikan informasi ekonomi (economic information) dari suatu kesatuan ekonomi (economy enity) kepada pihak-pihak yang berkepentingan (Priyati, 2013:1). Dari pengertian beberapa ahli diatas dapat disimpulkan bahwa Akuntansi adalah aktivitas jasa yang terdiri dari mencatat, mengklasifikasi dan melaporkan suatu transaksi atau kejadian ekonomi yang akhirnya akan menghasilkan suatu kesimpulan informasi laporan keuangan yang akan dibutuhkan oleh pihak tertentu untuk pengambilan keputusan.

\subsection{Akuntansi Sektor Publik}

Muindro (2013) Akuntansi sektor publik dapat di definisikan sebagai aktivitas jasa yang terdiri dari mencatat, mengklasifikasikan dan melaporkan kejadian atau transaksi ekonomi yang akhirnya akan menghasilkan informasi keuangan yang akan di butuhkan oleh pihak-pihak tertntu untukpengambilan keputusan yang diterapkan pada pengelolaan dana publik di lembaga-lembaga tinggi Negara dan departemen-departemen.

Rondonuwu (2015:23), Akuntansi sektor publik di indonesia pada berbagai entitas yakni sebagai berikut :

1. Akuntansi pusat

2. Akuntansi pemerintahan

3. Akuntansi Desa

4. Akuntansi Tempat Ibadah : Masjid, Gereja, Pura, Wihara

5. Akuntansi LSM

6. Akuntansi Yayasan

7. Akuntansi Pendidikan : Sekolah, Perguruan Tinggi

8. Akuntansi Kesehatan : Puskesmas, Rumah Sakit

\subsection{Akuntansi Pemerintahan}

Pada hakekatnya akuntansi pemerintahan adalah aplikasi akuntansi di bidang keuangan negara (Public Finance), Khususnya pada tahapan pelaksanaan anggaran (Butget execution), termasuk yang di timbulkannya, baik yang bersifat seketika maupun yang lebih permanen pada semua tingkatan dan unit pemerintahan, tuntutan transparansi dan akuntabilitas publik atas penggunanaan akuntansi dalam mencatan dan melaporkan kinerja pemerintahan, Dedi (2012:1).

Sadeli (2015:4) Menyatakan Akuntansi pemerintahan termasuk pula akuntasi lembaga-lembaga non profit atau Institusionl accounting. Mengkhususkan pada masalah pencatatan dan pelaporan transaksi dari unit-unit pemerintahan dan organisasi nonprofit lainya. Akuntansi pemerintahan dilaksanakan pada proses pencatatan dan pelaporan setiap transaksi yang terjadi pada proses pelaksanaan pemerintahan. Dari beberapa pendapat para ahli dapat disimpulkan bahwa akuntansi pemerintahan yang khususnya pada tahapan pencatatan, pelaporan, dan pelaksanaan anggaran termasuk segala pengaruh yang ditimbulkan pada suatu tingkat atau unit pemerintahan, baik itu bersiat sementara, ataupun permanen (Aremu at al, 2015).

\subsection{Akuntansi Desa}

Suharso (2016), Desa seharusnya berkewajiban menyelenggarakan akuntansi untuk mendukung proses akuntabilitas pengelolaan keuangannya kepada publik. Jika dihadapkan pada pilihan standar akuntansi ada saat ini, standar akuntansi yang cocok untuk akuntansi desa adalah Standar Akuntansi Pemerintahan (SAP). Setidaknya ada dua alasan yang dapat memperkuat pendapat ini. Pertama, desa bertanggungjawab mengurus urusan pemerintahan (UU 6/2014, Pasal 1) dam kepala desa wajib menyampaikan laporan penyelenggaranaan pemerintah desa kepada bupati/walikota (UU 6/2014, Pasal 27). Dua, alasan tersebut menunjukan hubungan yang erat antara aktifitas desa dengan aktivitas pemerintah. Rusmianto \& Yuliansyah (2016 : 5) Menyatakan Akuntansi Desa juga berperan dalam 
penyusunan Anggaran Pendapatan dan Belanja Desa (APBDes), Hal itu di pertegas dengan adanya keharusan untuk menyusun APBDes yang di jelaskan dalam Peraturan Mentri Dalam Negri (Permendagri) Nomor 113 Tahun 2014 Tentang Pengelolaan Keuangan Desa. Dengan diberikannya kewenangan pengelolan keuangan, maka Pemerintah Desa wajib untuk melaporkan kinerja kepada pemerintah dan masyarakat untuk menunjukan transparansi suatu laporan Pemerintah Desa.

\subsection{Sistem Akuntansi Desa}

Menurut Permendagri No 113 tahun 2014 Pengelolaan Keuangan Desa adalah keseluruhan kegiatan yang meliputi perencanaan, pelaksanaan, penatausahaan, pelaporan, dan pertanggungjawaban keuangan desa.

Menurut Permendagri No 113 Tahun 2014 Keuangan Desa adalah semua hak dan kewajiban desa yang dapat dinilai dengan uang serta segala sesuatu berupa uang dan barang yang berhubungan dengan pelaksanaan hak dan kewajiban desa.

Tahap Pengelolaan Keuangan Desa :

1. Perencanaan

2. Pelaksanaan

3. Penatausahaan

4. Pelaporan

5. Pertanggungjawaban

\subsection{Penelitian Terdahulu}

Suci Indah Hanifah (2015), dengan penelitian berjudul Akuntabilitas Dan Transparansi Pertanggungjawaban Anggaran Pendapatan Dan Belanja Desa. Hasil penelitiannya menunjukan bahwa Manajemen Keuangan Desa Kapatihan sudah berdasarkan Permendagri No. 37 Tahun 2007 yang menunjukan pelaksanaan yang akuntabel dan transparan yang dilihat dari pelaporan pertanggungjawaban APBDesa, namun dari sisi pencataan akuntansi masih diperlukan adanya pembinaan dan pelatihan lebih lanjut. Penelitian ini mempunyai kesamaan yang sana meneliti APBdes. Perbedaannya penelitian ini ingin mengetahui penerapan akuntansi dan manajemen keuangan di APBDes.

Made Wiradarma Setiawan (2017), dengan penelitian berjudul Analisis Transparansi dan Akuntabilitas Pelaporan Alokasi Dana Desa (Studi Kasus Desa Bengkel Kecamatan Busungbiu Kabupaten Buleleng. Hasil penelitian menunjukan bahwa Hasil penelitian menunjukkan bahwa (1) penyaluran Alokasi Dana Desa (ADD) dari Pemerintah Daerah ke Pemerintah Desa Bengkel sudah mengacu pada Peraturan bupati nomor 84 tahun 2015 tentang tata cara pengalokasian Dana Desa, Alokasi Dana Desa, Bagi Hasil Pajak, dan Bagi Hasil Retribusi dan pencairan dana dilakukan secara bertahap yaitu melalui empat tahapan yang dilengkapi dengan surat rekomendasi dari kecamatan, (2) pengimplementasian prinsip transparansi dan akuntabilitas pada Alokasi Dana Desa dapat dilihat pada saat melakukan perencanaan dan pembuatan laporan realisasi dan SPJ, (3) faktor yang mempengaruhi sulitnya. Persamaannya adalah sama-sama meneliti tentang APBDes. Perbedaannya adalah penelitian ini membahas tentang implementasi prinsip transparansi dan akuntabilitas dalam pertanggungjawaban pelaporan Alokasi Dana Desa.

\section{METODE PENELITIAN}

\subsection{Jenis dan sumber data}

Jenis data yang digunakan dalam penelitian ini adalah data kualitatif. Data tersebut berupa gambaran mengenai Desa Kopandakan I dan Laporan yang terkait dengan pelaksanaan APBDes. Dalam penelitian ini, penulis menggunakan data primer berupa data yang diperoleh langsung dari objek penelitian. Sedangkan, data sekunder yang digunakan adalah dari literatur- literatur, buku- buku yang bersangkutan dengan judul penelitian, dan penelitian- penelitian terdahulu. 


\subsection{Sampel dan teknik pengambilan sampel}

Teknik yang digunakan penulis dalam pengumpulan data adalah sebagai berikut:

1. Wawancara, dilakukan dengan cara tanya jawab dan diskusi langsung dengan pihak yang ditunjuk Kantor Desa Kopandakan I untuk menjelaskan tentang sistem pengendalian internal khususnya berhubungan dengan prosedur mengahasilkan bukti transaksi penerimaan dan pengeluaran serta prosedur pengakuntansian pelaksanaan APBDes yang diselenggarakan di desa kopandakan 1.

2. Dokumentasi, dengan mengumpulkan data secara langsung di kantor Desa Kopandakan I, yaitu data Laporan Realisasi Pelaksanaan APBDes, Laporan Pertanggungjawaban Realisasi Pelaksanaan APBDes, Laporan Realisasi Penggunaan Dana Desa.

3. Penelitian Kepustakaan, yaitu pengumpulan data dengan cara membaca dan mempelajari sumber-sumber kepustakaan berupa buku-buku literature peraturan perundang-undangan serta dokumen-dokumen yang berhubungan dengan penelitian yang dapat digunakan sebagai dasar teori yang melengkapi proses penyusunan skripsi ini.

\subsection{Metode analisis}

Metode analisis data yang digunakan ialah deskriptif, dimana data dikumpulkan, disusun, diinterpretasikan dan dianalisis sehingga memberikan keterangan yang lengkap bagi masalah yang dihadapi dengan cara :

1. Mengevaluasi sistem pengendalian internal dalam hal menghasilkan bukti transaksi dengan menggunakan teori SOP dan COSO.

2. Mengevaluasi Sistem Pencatatan yang diselenggarakan di desa Kopandakan I dengan cara membandingkan dengan Permendagri No. 113 Tahun 2014.

3. Mengevaluasi Pelaporan pelaksanaan APBDes di desa Kopandakan I dengan cara membandingkan dengan Permendagri No. 113 Tahun 2014.

\section{HASIL PENELITIAN DAN PEMBAHASAN}

4.1. Hasil Penelitian

1) Prosedur Pelaksanaan APBDes dalam hal menghasilkan bukti transaksi di Desa Kopandakan I

\section{Penerimaan}

a) Penerimaan melalui transfer ke rekening kas desa

Untuk Penerimaan Transfer, Bendahara Desa akan mendapat informasi dari Bank berupa Nota Kredit. Setiap penerimaan yang diterima disertai dengan kwitansi atau nota kredit dari bank, kemudian Bendahara melakukan pengecekan saldo rekening bank kas desa, jika saldo rekening sudah sesuai kemudian dicatat di buku bank dan buku kas umum lewat aplikasi SISKEUDES. Selain pencatatan pada Buku Kas Umum atau Buku Bank, Bendahara Desa juga membukukan realisasi pendapatan ke dalam Buku Rincian Pendapatan.

b) Penerimaan Tunai

Penerimaan Tunai yang di terima oleh Desa Kopandakan I bersumber dari Pendapatan Asli Desa, Hasil usaha, Swadaya, Partisipasi dan Gotong Royong, Hibah dan Sumbangan dari Pihak ke-3 serta Pendapatan Lain-lain yang sah. Berbeda dengan penerimaan transfer, penerimaan tunai ini penerimaan yang diterima oleh desa secara langsung namun setelah diterima, bendahara desa menyetorkannya ke rekening kas desa melalui bank setelah itu dilakukan pencatatan dalam BKU/Buku Bank lewat aplikasi SISKEUDES.

2. Pengeluaran

Proses menghasilakan bukti transaksi di desa Kopandakan I yaitu tim pelaksana kegiatan mengajukan surat pemintaan pembayaran, surat pertanggungjawaban belanja, nota pesanan (formulir terlampir). Setelah itu bendahara melakukan pencairan dana ke Bank 
berdasarkan SP2D yang di tandatangani oleh sangadi dan dana tersebut diserahkan kepada pelaksana kegiatan, penyerahan dana kepada pelaksana kegiatan dibuktikan dengan Kwitansi yang berisi Jumlah dana, maksud penyerahan dana dan sumber dana yang di tandatangani oleh pelaksana kegiatan, kordinator, bendahara dan sangadi. Setelah itu penyedia barang/jasa menerbitkan surat Kesanggupan Kerja, dan menyerahkan barang beserta Surat Penyerahan Hasil Kerja. Kemudian setelah barang di serahkan dengan membuat Berita Acara Penerimaan Barang, Berita Acara Pemeriksaan Barang dan Berita Acara Pembayaran beserta nota pembelian beserta bukti Surat Setoran Pajak. Sehingga nota pembelian ini menjadi bukti yang sah untuk dilakukan pencatatan ke aplikasi SISKEUDES pada buku kas umum.

\section{2) Pencatatan Pelaksanaan APBDes di desa Kopandakan I}

Proses pencatatan di desa Kopandakan I setiap terjadi transaksi langsung di lakukan pencatatan berdasarkan Bukti Transaksi dalam hal ini di catat pada Aplikasi Sistem Keuangan Desa (SISKEUDES) sesuai dengan jenis transaksi dalam :

1. Buku Kas Umum : Transaksi kas tunai yang ada di bendahara

2. Buku Bantu Bank
a) Penyetoran
: Mutasi dari kas bendahara ke Bank
b) Penarikan
: Mutasi dari Bank ke Kas Bendahara
c) Pajak
d) Bunga Bank
: Pengeluaran Pajak
e) Administrasi
: Penerimaan Pendapatan dari Bunga Bank
: Pengeluaran Administrasi

3. Buku Bantu Pajak : Pengenakan Pajak atas kegiatan yang dilaksanakan

4. Buku Bantu Kegiatan : Buku yang ada di Pelaksana Teknis Kegiatan

\section{3) Pelaporan Pelaksanaan APBDes di desa Kopandakan I}

Laporan-laporan yang ada di desa di desa Kopandakan I yang berhubungan dengan pelaksanaan APBDes adalah :

1. Laporan Realisasi Pelaksanaan APBDes

Laporan Realiasasi Pelaksanaan APBDes disampaikan kepada Walikota melalui Badan Pengelolaan Keuangan Daerah (BPKD), terdiri dari:

1) Laporan Semester Pertama, disampaikan paling lambat pada akhir bulan Juli tahun berjalan.

2) Laporan Semester Kedua, disampaikan paling lambat pada akhir bulan Januari tahun berikutnya.

Laporan ini dibuat Oleh Tim Pelaksana Kegiatan, Tim Pelaksana Pengelolaan Keuangan Desa, Sangandi, Sekertaris Desa, Bendahara Desa dan Laporan ini ditandatangani langsung Oleh Sangadi.

2. Laporan Realisasi Penggunaan Dana Desa

Laporan Realisasi Penggunaan Dana Desa disampaikan kepada Walikota melalui Badan Pengelolaan Keuangan Daerah (BPKD), terdiri dari:

1) Untuk semester I paling lambat minggu keempat bulan Juli tahun anggaran berjalan.

2) Untuk semester II paling lambat minggu keempat bulan Januari tahun anggaran berikutnya.

Laporan ini dibuat Oleh Tim Pelaksana Kegiatan, Tim Pelaksana Pengelolaan Keuangan Desa, Sangadi, Sekertaris Desa, Bendahara Desa dan Laporan ini ditandatangani langsung Oleh Sangadi.

3. Laporan Pertanggungjawaban Realisasi Pelaksanaan APBDes

Laporan ini dibuat Oleh Tim Pelaksana Kegiatan, Tim Pelaksana Pengelolaan Keuangan Desa, Sangandi, Sekertaris Desa, Bendahara Desa dan Laporan ini ditandatangani langsung Oleh Sangadi. 


\subsection{Pembahasan}

1) Evaluasi Sistem Pengendalian Internal dalam hal Menghasilkan Bukti

1. Evaluasi Prosedur Menghasilkan Bukti Transaksi Penerimaan

Desa Kopandakan I memiliki kelebihan dan kelemahan yang berkaitan dengan prosedur menghasilkan bukti transaksi penerimaan, yaitu :

1) Kelebihan, yaitu Setiap penerimaan yang diterima oleh bendahara disertai dengan kwitansi atau nota transfer dari bank, untuk transfer bendahara kemudian melakukan pengecekan saldo rekening kas desa, jika saldo rekening sudah sesuai kemudian dicatat di buku bank dan buku pendapatan lewat aplikasi SISKEUDES, untuk penerimaan tunai bendahara langsung menyetorkannya ke rekening kas desa melalui bank setelah itu langsung dilakukan pencatatan.

2) Kelemahan, yaitu tidak semua penerimaan disaksikan langsung oleh Sekdes dan Sangadi hanya dilaporkan oleh Bendahara kepada Sekdes dan Sangadi.

2. Evaluasi Prosedur Menghasilkan Bukti Transaksi Pengeluaran

Desa Kopandakan I memiliki kelebihan dan kelemahan yang berkaitan dengan prosedur menghasilkan bukti transaksi pengeluaran, yaitu :

1) Kelebihan, yaitu setiap pengeluaran tim pelaksana kegiatan mengajukan surat pemintaan pembayaran, surat pertanggungjawaban belanja, nota pesanan. Setelah itu bendahara melakukan penyerahan dana kepada pelaksana kegiatan dibuktikan dengan Kwitansi yang berisi Jumlah dana, maksud penyerahan dana dan sumber dana yang di tanda tangani oleh pelaksana kegiatan, kordinator, bendahara dan sangadi. Setelah itu penyedia barang/jasa menerbitkan surat Kesanggupan Kerja, dan menyerahkan barang beserta Surat Penyerahan Hasil Kerja. Kemudian setelah barang di serahkan dengan membuat Berita Acara Penerimaan Barang, Berita Acara Pemeriksaan Barang dan Berita Acara Pembayaran beserta nota pembelian beserta bukti Surat Setoran Pajak. Sehingga nota pembelian ini menjadi bukti yang sah untuk dilakukan pencatatan ke aplikasi SISKEUDES pada buku kas umum.

2) Kelemahan, tidak adanya SDM yang mempunyai pengetahuan tentang pemotongan pajak kegiatan sehingga mengakibatkan masalah dalam hal pemotongan pajak kegiatan.

3. Evaluasi Sistem Pengendalian Internal Untuk Prosedur Menghasilkan Bukti Transaksi

1. Lingkungan Pengendalian

Lingkungan pengendalian di desa Kopandakan I hanya dengan adanya struktur organisasi yang berdasarkan Perda Kota Kotamobagu No.42 Tahun 2008 serta pembagian tugas kegiatan yang tertuang dalam RPJMDes Tahun 2016, dimana setiap aparat Desa diberikan tugas dan tanggungjawab masing-masing dalam pelaksanaan APBDes sehingga Lingkungan Pengendalian yang dilaksanakan di desa Kopandakan I sudah memenuhi kriteria struktur organisasi serta pemberian wewenang dan tanggungjawab yang diharuskan oleh COSO.

2. Penaksiran Resiko

Penaksiran resiko pada pemerintah desa Kopandakan I berjalan dengan baik dimana tahun 2015 hingga 2016 dalam hal ini untuk proses pelaksanaan APBDes pemerintah desa Kopandakan I mengambil tindakan untuk melaksanakan seluruh penerimaan serta prosedur-prosedur yang berdasarkan aturan pemerintah dalam hal ini menggunakan aplikasi SISKEUDES karena aplikasi ini sudah di lengkapi juga dengan Sistem Pengendalian Intern (Built-in Internal Control) untuk meminimalisir terjadinya kesalahan dalam pelaksanaan APBDes sehingga sudah memenuhi kriteria aktivitas seperti pencatatan, pemrosesan, pengikhtisaran, dan pelaporan data-data keuangan yang disebutkan dalam COSO.

3. Aktivitas Pengendalian 
Aktivitas pengendalian dapat dikategorikan sebagai berikut.

a. Pengendalian Pemrosesan Informasi

a) pengendalian umum : segala sesuatu yang berhubungan dengan pelaksanaan APBDes harus diberifikasi oleh Sekdes dan disetujui oleh Sangadi.

b) pengendalian aplikasi : pengendalian aplikasi dalam hal ini aplikasi SISKEUDES dilakukan dengan cara hanya yang pihak intern desa Kopandakan I yang diberi tugas yang bisa mengakses segala sesuatu yang ada di dalam aplikasi tersebut.

c) otorisasi yang tepat : setiap penggunaan anggaran, bendahara bertugas untuk menyerahkan dana kepada tim pelaksana kegiatan sehingga tidak terjadi permainan oleh bendahara.

d) pencatatan dan dokumentasi : semua bukti transaksi di catat dan diarsipkan.

e) pemeriksaan independen : Sangadi melakukan pemeriksaan dan peninjauan langsung dari setiap kegiatan bersama BPD dan Sekdes.

b. Pemisahan tugas : Pemisahan tugas di Desa Kopandakan I sudah berjalan baik dan Jelas dengan adanya struktur organisasi serta pembagian tugas dan tanggungjawab.

c. Pengendalian fisik : Setiap kegiatan fisik harus disertai dengan bukti foto dan dilihat langsung oleh Sangadi.

d. Telaah kinerja : Dalam hal ini masalah pemotongan pajak langsung di ambil tindakan untuk berkonsultasi langsung ke kantor pajak mengenai masalah tersebut.

Aktivitas pengendalian yang dilaksanakan di desa Kopandakan I sudah berjalan dengan baik dimana dapat dilihat diatas bahwa seluruh kriteria dalam aktivitas pengendalian yang disebutkan oleh COSO sudah terpenuhi.

4. Informasi dan Komunikasi

Informasi dan komunikasi di desa Kopandakan I sudah berjalan baik dimana dengan digunakan Sistem Akuntansi Keuangan Desa (SISKEUDES) dan adanya komunikasi yang baik antara Sangadi dengan perangkat desa dan antara perangkat desa dengan perangkat desa lainnya maka kriteria yang disebutkan oleh COSO tentang Informasi dan Komunikasi mengenai Sistem Akuntansi yang berisi metode untuk mengidentifikasikan, menggabungkan, menganalisa, mengklasikasi, mencatat, dan melaporkan transaksi serta menjaga akuntabilitas aset dan kewajiban.

5. Pemantauan / Monitoring

Pemantauan / Monitoring di desa Kopandakan I dilakukan dengan baik dimana oleh Sangadi dimana setiap kegiatan diketahui oleh Sangadi serta terlibat langsung dalam menghasilkan bukti serta meninjau proses serta hasil dari kegiatan serta mengevaluasi hasil kegiatan sehingga Sangadi mengetahui langsung segala sesuatu yang berhubungan dengan pelaksanaan APBDes maka kriteria Pemantauan / Monitoring menurut COSO tentang kegiatan yang berlangsung secara terus menerus, evaluasi secara terpisah, atau dengan berbagai kombinasi dari keduanya sudah terpenuhi.

2) Evaluasi Sistem Pencatatan Pelaksanaan APBDes

Berdasarkan hasil penelitian yang di peroleh, dikarenakan desa kopandakan I telah menggunakan aplikasi sistem keungan desa (SISKUDES), aplikasi ini adalah aplikasi yang dibuat oleh Badan Pengawasan Keuangan dan Pembangunan, maka Sistem Akuntansi yang diselenggarakan desa Kopandakan I dalam pelaksanaan APBDes dua tahun terakhir telah memadai dan sesuai dengan Peraturan Menteri Dalam Negeri No. 113 Tahun 2014 Tentang Pengelolaan Keuangan Desa, terlebih di tahun 2016 desa Kopandakan I mengalami 
peningkatan karena telah menggunakan aplikasi sistem keuangan desa (SISKEUDES) dalam hal pengelolaan keuangan desa.

3) Evaluasi Pelaporan dan Penggunaan Kode Rekening

Berdasarkan hasil penelitian laporan Realisasi Pelaksanaan APBDes di desa Kopandakan I sudah memadai dan sesuai dengan Permendagri No. 113 Tahun 2014. Dapat dilihat bahwa di Tahun 2015 dan Tahun 2016 sudah sesuai dengan Permendagri No. 113 Tahun 2014.

Berdasarkan hasil penelitian, kode rekening yang digunakan dalam pencatatan dan pelaporan pemerintah desa Kopandakan I telah sesuai dengan Permendagri No. 113 Tahun 2014 karena dengan menggunakan aplikasi SISKEUDES maka semua kode rekening sudah diatur didalamnnya sesuai Petunjuk Pelaksanaan Bimbingan dan Konsultasi Pengelolaan Keuangan Desa yang diterbitkan oleh Badan Pengawasan Keuangan dan Pembangun (BPKP).

\section{KESIMPULAN DAN SARAN}

\subsection{Kesimpulan}

Berdasarkan hasil pembahasan di atas, maka dapat ditarik kesimpulan sebagai berikut:

1. Pengendalian internal dalam hal menghasilkan bukti transaksi yang dilaksanakan pemerintah desa Kopandakan I sudah berjalan dengan cukup baik.

2. Pencatatan dan Pelaporan yang di adakan di desa Kopandakan I sudah baik terlebih di tahun 2016 karena semuannya telah menggunakan aplikasi sistem keuangan desa dan sesuai dengan Petunjuk Pelaksanaan Bimbingan dan Konsultasi Pengelolaan keuangan Desa dan Permendagri No. 113 Tahun 2014.

3. Sistem Akuntansi Pelaksanaan APBDes yang di selenggarakan di desa Kopandakan I Kecamatan Kotamobagu Selatan Kota Kotamobagu telah sesuai dengan Petunjuk Pelaksanaan Bimbingan dan Konsultasi Pengelolaan keuangan Desa dan Permendagri No. 113 Tahun 2014 namun

4. Aparat Desa Kopandakan I terkadang mempunyai masalah dalam proses pelaksanaan APBDes dalam hal pemotongan pajak kegiatan dikarenakan minimnya pengetahuan tentang perpajakan dan tingkat pendidikan aparat desa Kopandakan I tergolong rendah, hanya beberapa orang saja yang berpendidikan tinggi.

\subsection{Saran}

Berdasarkan kesimpulan diatas, maka saran dalam penelitian ini adalah :

1. Mengingat Sistem Akuntansi dalam pelaksanaan APBDes sangat penting, maka diharapkan agar pemerintah desa Kopandakan I mencari sumber daya manusia yang memang mempunyai keahlian di bidang pengakuntansian.

2. Diharapkan juga peran dari Tim Pendamping tingkat Kecamatan untuk dapat membantu perangkat desa terkait pelaksanaan dan pelaporan APBDes di desa Kopandakan I.

\section{DAFTAR PUSTAKA}

Aremu, Y, S, Babalola, B, Aninkan, O, D, and Saloko, M, A, 2015. Analisis Of Inpact Of Sectoral Goverment Expeditures On Economic Growth In Nigeria : bound test cointegration approach. European Jurnal of Business And Management, Vol, 7(12) : 2222-2839.

COSO. 2013. Internal Control - Integrated Framework : Executive Summary, Durham, North Carolina, May 2013

Dedi, Wiranta, 2012. Akuntansi Sektor Publik, Pengertian Akuntansi Pemerintahan, Pustaka Baru Press. 
Francis Pol C, Lim, (2013). Inpact Of Informatian Technology On Accounting System,Jurnal Of Multimedia Services Convergent With Art, Humanities And Sociology Vol. 3 (2):93-106.

Made Wiradarma Setiawan. 2017. Journal S1 Ak Universitas Pendidikan Ganesha Jurusan Akuntansi Program S1 (Vol: 7 No: 1 Tahun 2017)

Muindro Renyowijoyo. 2013. Akuntansi Sektor Publik. Jakarta : Mitra Wacana Media

Priyati, Novi. 2013. Pengnantar Akuntansi.Penerbit Indeks Jakarta.

Republik Indonesia. 2014. Peraturan Menteri Dalam Negeri Nomor 113 tahun 2014 Tentang Pengelolaan Keuangan Desa. Jakarta.

Republik Indonesia. 2014. Undang-Undang Nomor 6 Tahun 2014 Tentang Desa, Lembaran Negara Republik Indonesia Tahun 2014 Nomor 7, Tambahan Lembaran Negara Nomor 5495.

Rondonuwu, 2015. Analisis Efisiensi Dan Efektivitas Pengelolaan Keuangan Daerah Pada Dinas Pendapata Daerah Kabupaten Minahasa. Jurnal Emba Vol. 3 No. 4 Desember 2015. Hal. 23-32.

Sadeli, Lili, 2015. Dasar-Dasar Akuntansi. Edisi Pertama, Bumi Aksara Jakarta.

Sayuti, Jalaludin. 2012. Pentingnya Standar Operasional Prosedur Untuk Meningkatkan Kinerja Karyawan dalam Perusahaan. Jurnal Administrasi Bisnis. Vol IV, No. 3.

Suci Indah Hanifah, 2015. Akuntabilitas Dan Transparansi Pertanggungjawaban Apbdes, Jurnal Ilmu \& Riset Akuntansi Vol. 4 No. 82015.

Suharso, 2016. Tinjauan Akuntansi Desa, Mitra Wacana Medi Jakarta.

Warren, Carl S., Reeve, James M., Duchac, Jonathan E. (2011). Principles of Accounting (24th edition). South Western: Cengage Learning. 